\title{
Immune-based mechanisms of cytotoxic chemotherapy: implications for the design of novel and rationale-based combined treatments against cancer
}

\author{
L Bracci ${ }^{*, 1}$, G Schiavoni ${ }^{1}$, A Sistigu ${ }^{1}$ and $F$ Belardelli ${ }^{1}$
}

Conventional anticancer chemotherapy has been historically thought to act through direct killing of tumor cells. This concept stems from the fact that cytotoxic drugs interfere with DNA synthesis and replication. Accumulating evidence, however, indicates that the antitumor activities of chemotherapy also rely on several off-target effects, especially directed to the host immune system, that cooperate for successful tumor eradication. Chemotherapeutic agents stimulate both the innate and adaptive arms of the immune system through several modalities: (i) by promoting specific rearrangements on dying tumor cells, which render them visible to the immune system; (ii) by influencing the homeostasis of the hematopoietic compartment through transient lymphodepletion followed by rebound replenishment of immune cell pools; (iii) by subverting tumor-induced immunosuppressive mechanisms and (iv) by exerting direct or indirect stimulatory effects on immune effectors. Among the indirect ways of immune cell stimulation, some cytotoxic drugs have been shown to induce an immunogenic type of cell death in tumor cells, resulting in the emission of specific signals that trigger phagocytosis of cell debris and promote the maturation of dendritic cells, ultimately resulting in the induction of potent antitumor responses. Here, we provide an extensive overview of the multiple immune-based mechanisms exploited by the most commonly employed cytotoxic drugs, with the final aim of identifying prerequisites for optimal combination with immunotherapy strategies for the development of more effective treatments against cancer.

Cell Death and Differentiation (2014) 21, 15-25; doi:10.1038/cdd.2013.67; published online 21 June 2013

Facts

(1) Immune competence is crucially required for chemotherapy efficacy.

(2) The antitumor effects of chemotherapy rely on tumor-host interplay.

(3) Tumor-induced immune tolerance needs to be overcome in order to allow the full recovery of immune surveillance and hamper tumor spreading or recurrence.

(4) The capability of some cytotoxic drugs to induce an immunogenic cell death makes apoptotic tumor cells a good endogenous vaccine.

(5) Some cytotoxic agents induce a lymphodepletionassociated bystander immune stimulation.

\section{Open Questions}

(1) Patient's immune status and tumor cells' intrinsic characteristics need to be investigated deeper, so as to identify the requisites predicting full benefit of defined single or combined anticancer treatments.
(2) Off-target effects of chemotherapy need further elucidation in order to allow a rationale-based, rather than empirical, selection of combinatorial regimens.

(3) Adjuvant chemotherapy regimens using cytotoxic drugs with immunomodulatory properties, possibly in combination with immunotherapy approaches, should be evaluated as strategies for tertiary prevention of cancer.

(4) Strategies to be pursued should be aimed at selectively hitting tumor-induced inhibitory cells/mechanisms, sparing effector cells and other subsets capable of suppressing undesirable autoimmune responses.

Conventional anticancer chemotherapy is generally thought to act through selective killing of tumor cells or by irreversibly arresting their growth. Cytotoxic drugs interfere with DNA synthesis, or produce chemical damage to DNA, ultimately leading to tumor cell death (TCD; see Table 1). However, this concept neglects the possible contribution of the host to the therapeutic process of chemotherapy. Accumulating evidence indicates that several chemotherapeutic drugs are more efficient against tumors that are implanted in immunocompetent, with respect to immunodeficient, hosts. ${ }^{1}$

\footnotetext{
${ }^{1}$ Department of Hematology, Oncology and Molecular Medicine, Istituto Superiore di Sanità, Rome, Italy

*Corresponding author: L Bracci, Department of Hematology, Oncology and Molecular Medicine, Istituto Superiore di Sanitã, viale Regina Elena 299, Rome 00161, Italy. Tel: +39 064990 2474; Fax: +39 064990 2714; E-mail: laura.bracci@iss.it

Keywords: chemotherapy; cancer; immune system; cellular immunity; combined therapies

Abbreviations: DC, dendritic cell; NK, natural killer; TAM, tumor-associated macrophages; M1, classically activated macrophages; M2, alternatively activated macrophages; Treg, regulatory T; MDSC, myeloid-derived suppressor cell; CTX, cyclophosphamide; 5-FU, 5-Fluorouracil; NO, nitric oxide; iNOS, inducible nitric oxide synthase; TCD, tumor cell death; BM, bone marrow; LN, lymph node; HSPs, heat shock proteins; VEGF, vascular endothelial growth factor; HMGB1, high-mobility group box-1; ecto-CRT, surface-exposed calreticulin; TK, tyrosine kinase; mTOR, mammalian target of rapamycin

Received 11.2.13; revised 07.5.13; accepted 14.5.13; Edited by M Piacentini; published online 21.6.13
} 
Table 1 Biochemical and biological properties of conventional antineoplastic drugs

\begin{tabular}{|c|c|c|c|c|}
\hline Class & Examples & Biochemical activity & Biological effects & Use in clinical oncology \\
\hline Antimetabolites & $\begin{array}{l}\text { 5-Fluorouracil } \\
\text { Gemcitabine } \\
\text { Methotrexate }\end{array}$ & $\begin{array}{l}\text { Analog of pyrimidine } \\
\text { nucleoside }\end{array}$ & $\begin{array}{l}\text { Reduction of folates } \\
\text { required for DNA synthesis }\end{array}$ & $\begin{array}{l}\text { Colorectal cancer, pancreatic cancer } \\
\text { Non-small cell lung cancer, pancreatic } \\
\text { cancer, bladder cancer, breast cancer } \\
\text { Breast, head and neck, leukemia, lymphoma, } \\
\text { lung, osteosarcoma, bladder and } \\
\text { trophoblastic neoplasms }\end{array}$ \\
\hline Alkylating agents & $\begin{array}{l}\text { Cyclophosphamide } \\
\text { Dacarbazine } \\
\text { Melphalan }\end{array}$ & $\begin{array}{l}\text { Adds an alkyl group to } \\
\text { DNA }\end{array}$ & Inhibition of DNA replication & $\begin{array}{l}\text { Lymphomas, leukemias, brain tumors } \\
\text { Metastatic melanoma, Hodgkin's lymphoma } \\
\text { Multiple myeloma, ovarian cancer, malignant } \\
\text { melanoma }\end{array}$ \\
\hline Anthracyclines & Doxorubicin & $\begin{array}{l}\text { Intercalates base pairs } \\
\text { of nucleic acids }\end{array}$ & $\begin{array}{l}\text { Inhibition of RNA and DNA } \\
\text { synthesis }\end{array}$ & $\begin{array}{l}\text { Leukemias, Hodgkin's lymphoma, bladder } \\
\text { cancer, breast, stomach, lung, ovaries, } \\
\text { thyroid, soft-tissue sarcoma, multiple } \\
\text { myeloma }\end{array}$ \\
\hline $\begin{array}{l}\text { Antimicrotubule } \\
\text { agents }\end{array}$ & Vinblastine & $\begin{array}{l}\text { Binds tubulin, thereby } \\
\text { inhibiting the assembly } \\
\text { of microtubules }\end{array}$ & $\begin{array}{l}\text { M-phase-specific cell cycle } \\
\text { arrest by disrupting } \\
\text { microtubule assembly }\end{array}$ & $\begin{array}{l}\text { Hodgkin's lymphoma, non-small cell lung } \\
\text { cancer, breast cancer, head and neck } \\
\text { cancer, and testicular cancer }\end{array}$ \\
\hline $\begin{array}{l}\text { Platinum } \\
\text { compounds }\end{array}$ & $\begin{array}{l}\text { Cisplatin } \\
\text { Oxaliplatin }\end{array}$ & Crosslinks DNA strands & $\begin{array}{l}\text { Inhibition of DNA replication } \\
\text { and transcription }\end{array}$ & $\begin{array}{l}\text { Head and neck, lung and ovarian } \\
\text { carcinomas, lymphomas, germ cell tumors } \\
\text { Colorectal cancer }\end{array}$ \\
\hline Taxanes & $\begin{array}{l}\text { Paclitaxel } \\
\text { Docetaxel }\end{array}$ & $\begin{array}{l}\text { Stabilizes GDP-bound } \\
\text { tubulin in microtubules }\end{array}$ & Inhibition of mitosis & $\begin{array}{l}\text { Lung, ovarian, breast, head and neck cancer, } \\
\text { advanced forms of Kaposi's sarcoma } \\
\text { Breast, ovarian, prostate and non-small cell } \\
\text { lung cancer }\end{array}$ \\
\hline \multirow[t]{3}{*}{$\begin{array}{l}\text { Topoisomerase } \\
\text { inhibitors }\end{array}$} & Irinotecan & $\begin{array}{l}\text { Interferes with type I } \\
\text { topoisomerases } \\
\text { inducing DNA strands } \\
\text { breaks }\end{array}$ & $\begin{array}{l}\text { Cell cycle arrest and } \\
\text { apoptosis }\end{array}$ & Colorectal cancer \\
\hline & $\begin{array}{l}\text { Etoposide } \\
\text { phosphate }\end{array}$ & $\begin{array}{l}\text { Interferes with type II } \\
\text { topoisomerases } \\
\text { inducing DNA strands } \\
\text { breaks }\end{array}$ & & $\begin{array}{l}\text { Kaposi's and Ewing's sarcomas, certain } \\
\text { leukemias, lung, ovarian, gastrointestinal } \\
\text { cancers, glioblastoma multiforme }\end{array}$ \\
\hline & Mitoxantrone & & & $\begin{array}{l}\text { Metastatic breast cancer, acute myeloid } \\
\text { leukemia and non-Hodgkin's Iymphoma }\end{array}$ \\
\hline
\end{tabular}

Conventional chemotherapy can stimulate the immune system in two ways. Some agents elicit cellular rearrangements that render dying tumor cells visible to the immune system. Other drugs induce a transient lymphodepletion, subvert immunosuppressive mechanisms, or exert direct or indirect stimulatory effects on immune effectors. Immunomodulatory properties are being ascribed also to targeted chemotherapeutic agents, that is, compounds designed to hit biochemical pathways essentially required for tumor cell survival and/or growth (Box 1). All these observations open to the intriguing possibility that immunomodulatory chemotherapeutic agents may be good candidates for combination with immune-based therapeutic approaches.

This review will provide an overview on the immune-based mechanisms exploited by some cytotoxic drugs (Figure 1), with the final aim of identifying prerequisites for optimal combination with immunotherapy strategies for the development of more effective, rationale-driven treatments against cancer.

\section{Effects on the Innate Immune System}

Several direct effects of cytotoxic drugs have been described for macrophages, dendritic cells (DCs) and natural killer (NK) cells. Earlier studies on NK-cell function in cancer patients undergoing cytotoxic chemotherapy have shown variable effects, especially in correlation with the clinical outcome., ${ }^{2,3}$ In breast cancer patients with localized and metastatic disease, cytotoxic drug regimens were shown to induce an overall impairment of NK-cell responses. ${ }^{4,5}$ Recently, a metronomic (that is, low dosage for a prolonged period of time) cyclophosphamide (CTX) regimen was shown to potently stimulate NK-dependent antitumor immunity in end-stage cancer patients ${ }^{6}$ and the prompt recruitment of DCs, macrophages and NK cells to the tumor site in diverse mouse models. ${ }^{7,8}$ Interestingly, combined treatment with 5-Fluorouracil (5-FU) and IFN- $\alpha$ resulted in higher numbers of infiltrating NK cells with enhanced cytotoxicity in a pancreatic tumor model. ${ }^{9}$

Effects of chemotherapy on macrophages have also been documented. Macrophages can differentiate from blood monocytes into two distinct subtypes, namely classically activated (M1) and alternatively activated (M2) macrophages endowed with effector or suppressive functions, respectively. ${ }^{10,11}$ Macrophages infiltrating solid tumors (that is, tumor-associated macrophages or TAMs) share many characteristics with M2 macrophages and exert a pro-tumorigenic function in virtue of their direct or indirect (via cytokine production) immune-suppressive effects towards NK and T-cells. ${ }^{12}$ In cancer patients, the presence of TAMs favors tumor progression. ${ }^{12}$ Several studies have investigated the 


\section{Box 1 Immune-based effects of targeted anticancer compounds}

Targeted therapies act by blocking biochemical pathways or mutant proteins essentially required for tumor cell growth and survival. Most targeted therapies induce dramatic tumor regressions, although long-term clinical benefit is hampered by the occurrence of drug-resistant variants. Similar to conventional chemotherapeutic agents, some targeted agents display immunomodulatory properties. The receptor tyrosine kinase (TK) inhibitor sunitinib dampens the immunosuppressive activity of Treg and MDSCs, ${ }^{133,134}$ whereas the TK inhibitor imatinib challenges IDO expression in myeloid cells. ${ }^{135}$ mTOR kinase inhibitors (e.g., everolimus, temsirolimus) trigger autophagy and inhibit angiogenic activity by both direct effects on vascular cell proliferation and indirect effects on growth factor production. ${ }^{106}$ Diverse Janus kinase inhibitors, small molecules interfering with cytokine signaling, prove effective in stimulating DC maturation and antigen-specific T-cell priming. ${ }^{136}$ The proteasome inhibitor Bortezomib, which is approved for use in multiple myeloma, sensitizes tumor cells to TRAIL- and NK-mediated cell lysis. ${ }^{137}$ Vemurafenib, a specific BRAF inhibitor recently approved for treatment of some melanomas, enhances the expression of several tumor antigens, enabling immune recognition by T lymphocytes. ${ }^{138}$ Trastuzumab and cetuximab, monoclonal antibodies directed against tumor-associated receptor TK HER-2 and EGFR, respectively, augment antigen presentation through the formation of immune complexes, leading to stimulation of T-cell-mediated immune responses. ${ }^{139,140}$ Altogether, these observations pave the way to clinical studies aimed at evaluating the possible synergism of targeted compounds and immunotherapy strategies.

effects of cytotoxic chemotherapy in subverting the protumorigenic activities of macrophages. For example, lowdose CTX can promote the skewing of M2 macrophages into M1 in vivo, thus enhancing the production of oxygen radicals, IL-6 and IL-12, and potentiating innate responses. ${ }^{13}$ Similarly, in mice bearing B16.F10 melanoma, combined treatment with vincristine, CTX and doxorubicin resulted in substantial enrichment of a TAM subpopulation that can be M1-polarized upon concomitant immunotherapy. ${ }^{14}$ Interestingly, whereas tumor sensitivity to CTX or cisplatin in vitro is increased when tumor cells are cultivated with macrophages, coculture of macrophages with human primary ovarian tumor cells decreased tumor sensitivity to $5-\mathrm{FU} .^{15}$ Likewise, the taxane paclitaxel can stimulate TAMs cytotoxicity directly ${ }^{16}$ and induce the activation of DCs, NK and tumor-specific CTL via the secretion of IL-12 and TNF- $\alpha$ and inducible nitric oxide synthase (iNOS) by TAMs, ${ }^{17}$ resulting in tumor regression. Conversely, paclitaxel-induced influx of TAMs was detrimental to chemotherapy response in mouse mammary carcinoma and breast cancer patients. ${ }^{18,19}$

Chemotherapy has influence on bone marrow (BM) hematopoiesis, affecting myeloid cell mobilization differentially. A single injection of low-dose CTX was shown to spare DC precursors in the BM, promoting their expansion and differentiation in the peripheral lymphoid organs. CTX exerted its effects preferentially on the CD $8 \alpha$-expressing-DC subset, determining an initial ablation of lymphoid organ-resident CD $8 \alpha^{+}$DCs, followed by overshoot replenishment after drug discontinuation. ${ }^{20,21}$ Data from our laboratory have revealed that, after CTX administration, CD $8 \alpha^{+}$DCs migrate to the tumor site where they cross-present tumor-associated antigen (Figure 2). The platinum-based compound cisplatin was also reported to modulate the percentages of myeloid cells by increasing DCs and eliminating myeloid-derived suppressor cells (MDSCs), thus favoring immune effector responses in melanoma-bearing mice. ${ }^{22}$ Moreover, an overall increase of $\mathrm{CD} 14^{+}$monocytes, CD11c ${ }^{+}$myeloid DCs and CD123 ${ }^{+}$ plasmacytoid DCs was observed in patients with advanced pancreatic cancer receiving gemcitabine for 2 months, with respect to untreated patients. ${ }^{23}$

Direct immunostimulatory effects of cytotoxic drugs on DC activities were also reported. An unbiased functional screen of 54 chemotherapeutic agents unveiled striking diversity of the tested drugs on the maturation, survival and growth of DCs. ${ }^{24}$ The drugs delivering DC maturation signals at concentrations causing only marginal DC death included topoisomerase inhibitors (for example, etoposide, mitoxantrone, doxorubicin), antimicrotubule agents (for example, vinblastine, paclitaxel, docetaxel) and the two alkylating agents mechlorethamine and diaziquone. ${ }^{24}$ In another report, paclitaxel, doxorubicin and methotrexate were shown to promote the ability of murine BM-DCs to present antigens to T-cells in vitro by upregulating antigen-processing machinery gene components, costimulatory molecules and IL-12p70. ${ }^{25}$ Similar results were observed with human monocyte-derived DCs. ${ }^{26}$ Notably, vinblastine at low concentrations $(0.1-1 \mu \mathrm{M})$ induces phenotypic and functional maturation of DCs in vitro and in vivo, when injected into the skin of mice, by triggering in situ maturation of skin-resident DCs and by boosting humoral and cellular immune responses. ${ }^{27} \mathrm{~A}$ recent study on human 6-sulfo LacNAc ${ }^{+}$(slan) DCs, a major subpopulation of human blood DCs, showed that doxorubicin impairs the ability of these cells to produce proinflammatory cytokines and to activate $\mathrm{T}$ lymphocytes and NK cells, whereas methotrexate and paclitaxel sustain their effector properties. ${ }^{28}$

Cytotoxic chemotherapy can affect DC activities also through indirect mechanisms. Pioneering studies showed that 5-FU and doxorubicin induced in vitro cancer expression of heat shock proteins (HSPs) that promote the engulfment of cell debris by human DCs and the subsequent crosspresentation of tumor antigens to T-cells. ${ }^{29,30}$ More recently, Casares et al. ${ }^{31}$ showed that doxorubicin-killed tumor cells elicit tumor-specific immune responses when injected into syngeneic mice, by stimulating DC phagocytosis and CD8 T-cell responses. Subsequent work from L. Zitvogel's laboratory identified the molecular mechanism linking immunogenic apoptosis induced by chemotherapy to DC activation, as detailed below.

\section{Effects on the Adaptive Immune System}

Treatment of cancer patients with intensive chemotherapy results in profound depletion of all lymphocytic populations, especially of B cells. ${ }^{32,33}$ A study conducted on breast cancer patients to evaluate the effect of combination chemotherapy regimens with epirubicin (5-FU, epirubicin, CTX) versus doxorubicin (5-FU, doxorubicin, CTX) on subsets of immune cells revealed an increase in the percentages of cytotoxic $T$ and NK cells, and a dramatic decrease in that of B cells in the blood following either regimen. ${ }^{34}$ Similarly, repeated gemcitabine cycles reduced $B$ cell frequencies and induced a profound suppression of antigen-specific IgG antibody 


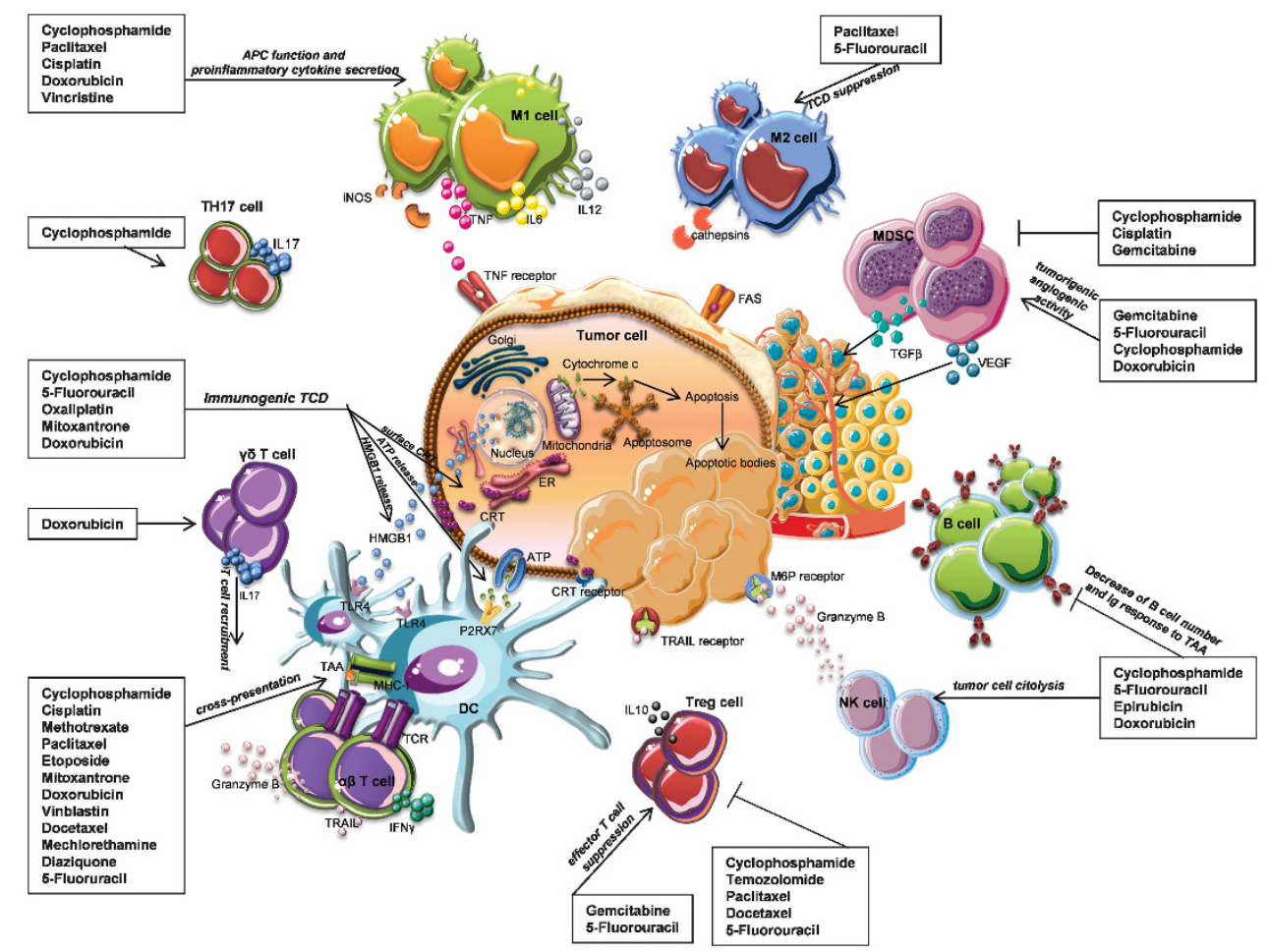

Figure 1 Immunomodulation by conventional cytotoxic drugs. Conventional antineoplastic drugs can activate anticancer immune responses through different mechanisms: (i) the inhibition of tumor-induced-suppressive mechanisms, (ii) the direct stimulation of $\mathrm{T}$ and $\mathrm{B}$ cell responses, (iii) the enhancement of tumor immunovisibility by cytotoxic cell subsets or phagocytes. Low-dose CTX and gemcitabine deplete regulatory T-cells or myeloid suppressor cells and facilitate tumor attack by effectors. Paclitaxel, cisplatin and doxorubicin induce the upregulation of mannose-6-phosphate receptors on the surface of tumor cells, rendering them permeable to granzyme B. Paclitaxel induces proinflammatory cytokines' secretion from macrophages, leading to DC, NK and T-cell activation. Anthracyclines, oxaliplatin and CTX promote tumor expression of ecto-CRT, and release of HMGB1 and ATP by dying tumor cells, thus stimulating antigen phagocytosis and cross-presentation by DC

responses, but enhanced T-cell responses, in a mouse model of malignant mesothelioma. ${ }^{35}$ The reason for this differential effect on the two lymphocytic populations was partly attributed to an increased sensitivity of $B$ cells to the antiproliferative effects of gemcitabine in vitro, with respect to T-cells, ${ }^{35}$ although it is not clear whether this mechanism also applies in vivo, or in the case of other chemotherapeutic agents. Instead, gemcitabine given at a single dose $(120 \mathrm{mg} / \mathrm{kg})$ preserved both $\mathrm{T}$ and $\mathrm{B}$ lymphocytes in the spleens of animals bearing large tumors, ${ }^{36}$ and 5-FU-based adjuvant chemotherapy induced prominent tumor-specific antibody responses in colon cancer patients. ${ }^{37}$

The effects of CTX on humoral responses appear controversial. In some reports, CTX, even at low-dose regimens, exerted suppressive effects on humoral responses while boosting cellular responses, suggesting that $\mathrm{B}$ cells are particularly sensitive to CTX-induced cytotoxic effects. ${ }^{38,39}$ In other reports, low-dose CTX was shown to increase the relative percentages of $B$ and T-cells in mice bearing SW1C melanoma, ${ }^{7}$ and the cellular and antibody responses in patients with advanced cancer. ${ }^{40}$ Subsequent studies showed that the lymphodepleting effects induced by CTX are transient and that, soon after drug discontinuation, a homeostatic rebound overshoot of the lymphocytic pool occurs. ${ }^{41,42}$ This implies that after drug administration, a reduction of both humoral and cellular responses may occur, but with different timing and kinetics. It has been proposed that the homeostatic replenishment of $B$ and $T$ lymphocyte compartments is sustained by a drug-induced 'cytokine storm' during which several hematopoietic and homeostatic factors, danger signals, pattern recognition receptors, inflammatory mediators and growth factors are expressed, thus boosting peripheral expansion. ${ }^{41,43}$ One might speculate that these mediators cooperate in sensing and amplifying drug-induced myelo- and lymphotoxicity, thus stimulating a DNA damage response that, in turn, promotes immune activation. Interestingly, genotoxic stress activates the expression of IFN- $\alpha$ and IFN- $\lambda$ genes, leading to the ultimate stimulation of immune responses resembling those evoked during viral infections. ${ }^{44}$ In addition, CTX and fludarabine combination greatly improved the therapeutic efficacy of adoptively transferred tumor-specific B cells in a mouse melanoma model of experimental metastasis. ${ }^{45}$ Likewise, combined high-dose CTX and doxorubicin treatment augmented long-lasting humoral response in vivo to a cancer vaccine. ${ }^{46}$

Numerous evidence indicate the benefits of chemotherapy on T-cell-mediated immune responses. Mice vaccinated with doxorubicin- or cisplatin-treated ovarian cancer cells have enhanced antitumor immunity, and prolonged survival largely dependent on CD4 T-cell-mediated immune responses. ${ }^{47}$ Low-dose cisplatin and paclitaxel synergize to generate strong tumor-specific CD8 T-cell responses, through IL-2 
a

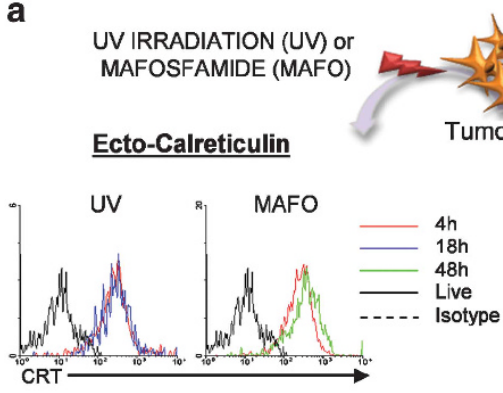

b

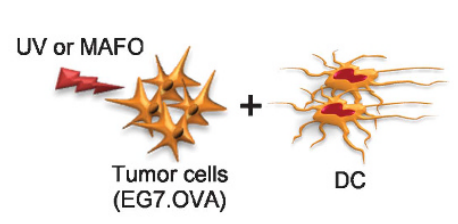

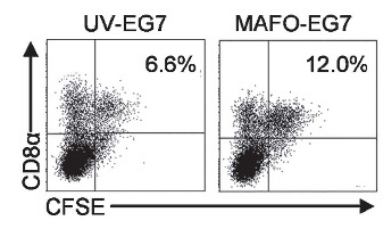

C

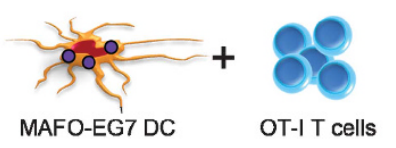

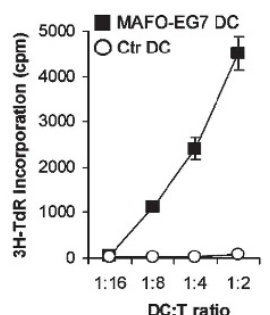

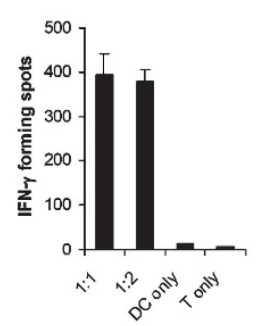

d

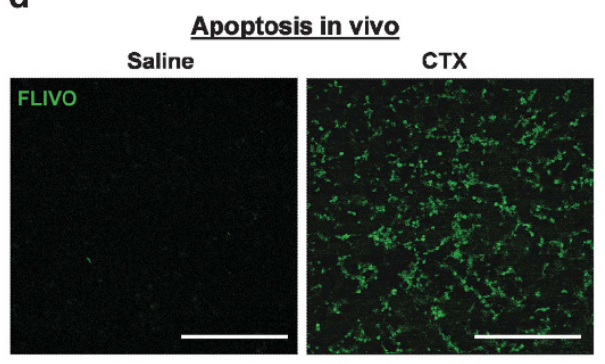

e Cross-presentation in vivo

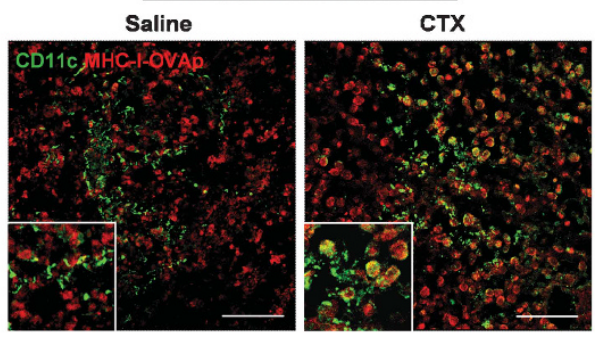

Figure 2 Induction of immunogenic tumor cell death and stimulation of DC cross-presentation by CTX in vitro and in vivo. (a) Ecto-CRT exposure at $4 \mathrm{~h}$ and extracellular HMGB1 release (48 $\mathrm{h}$ ) in tumor cells following UV irradiation or treatment with the CTX-analog Mafosfamide (MAFO). (b) In vitro uptake of CFSE-labeled OVA-expressing EG7 tumor cells, killed by UV irradiation or MAFO treatment, by splenic CD8 $\alpha+$ DC. (c) Stimulation of OT-I CD8 T-cell cross-priming by CD8 $\alpha+$ DC that had captured MAFO-killed EG7 tumor cells. Proliferative response (left) and IFN- $\gamma$ ELISPOT assay (right) are shown. (d) Induction of tumor apoptosis in EG7 tumor-bearing mice 2 days after a single injection of CTX (100 mg/kg), as detected by FLIVO staining in the tumor tissue. (e) In situ cross-presentation of tumor-associated antigen by tumor-infiltrating DC in mice bearing EG7 tumors following CTX injection (7 days). Co-expression of CD11c and OVA-derived peptide SIINFEKL bound to MHC class I (MHC-I-OVAp) in EG7 tumor tissue sections were detected by confocal laser-scanning microscopy. Modified from Schiavoni et $\mathrm{al}^{21}$

and IFN- $\gamma$ secretion, and high therapeutic efficacy on platinum-resistant ovarian cancers in both mice and patients. ${ }^{48} 5$-FU was also reported to increase IFN- $\gamma$ production by tumor-specific CD8 T-cells infiltrating the tumor, and to boost T-cell-dependent antitumor responses by in vivo elimination of MDSCs. ${ }^{49}$ In both mouse models and patients with esophageal squamous cell carcinoma, neoadjuvant chemotherapy with 5-FU and cisplatin increased the intratumoral trafficking of CD4 and CD8 T-cells. ${ }^{50,51}$ In experimental carcinogen-induced adenocarcinomas and fibrosarcomas, doxorubicin treatment enhanced tumor-specific proliferation of CD8 T-cells in tumor-draining lymph nodes (LNs) and promoted tumor infiltration of activated, IFN- $\gamma$-producing CD8 T-cells. ${ }^{52}$ In this setting, therapeutic efficacy of doxorubicin required both IL-1 $\beta$ and IL-17, and the presence of $\gamma \delta$ T-cells.

A single CTX injection potently enhances the antitumor response of tumor-bearing mice following adoptive transfer of tumor-reactive T-cells. ${ }^{42,53,54}$ Several mechanisms have been proposed to explain this effect: (i) drug-induced bystander proliferation of memory CD4 and CD8 T-cells; ${ }^{55}$ (ii) drug-induced stimulation of CD8 T-cells proliferation and IFN- $\gamma$ production; ${ }^{41}$ (iii) differentiation of adoptively transferred antigen-specific CD4 T-cells into activated polyfunctional $\mathrm{T}$ helper cells with potent antitumor activity; ${ }^{56}$ (iv) specific homing of transferred T-cells to the lymphoid organs and tumor mass soon after drug discontinuation. ${ }^{41,57}$ Accordingly, the therapeutic efficacy of combined CTX and adoptive transfer of tumor-specific spleen cells was shown to critically require donor CD4 T-cells. ${ }^{42}$ Combined treatment with anti-41BB and CTX produced synergistic CD8-mediated anticancer effects in the B16 melanoma mouse model. ${ }^{58}$

Evidence for the positive impact of chemotherapy on antitumor immune responses also arises from pilot clinical trials with cancer vaccines. Gene expression analysis of peripheral blood mononuclear cells (PBMCs) from melanoma patients treated with dacarbazine and a peptide-based vaccine revealed, by 1 day after chemotherapy, increased expression of immunoregulatory factors that can account for the enhancement of tumor antigen-specific CD8 T-cell responses observed in those patients, compared with patients treated with vaccine alone. ${ }^{59}$ These effects were paralleled by a widening of the antigenic repertoire and by an expansion of antigen-specific T-cell tumor reactivity. ${ }^{60}$

Cancer often results in an imbalance of Th1/Th2 immunity, which can be restored by some antineoplastic drugs. As an example, paclitaxel augments Th1 cellular immunity in patients with advanced non-small cell lung cancer by increasing the levels of circulating IFN- $\gamma$-secreting CD8 
T-cells and IL-2-secreting CD4 T-cells. ${ }^{61}$ Moreover, CTX induces Th1-polarizing cytokines (IL-2 and IFN- $\gamma$ ) and decreases Th2 cytokines (IL-4 and IL-10) both in tumorbearing mice ${ }^{41}$ and rats. ${ }^{62}$ Notably, in tumor-bearing mice CTX increased the frequencies of splenic Th1 and Th17 cells, which displayed a faster recovery from drug-induced lymphodepletion, with respect to Treg cells. ${ }^{43}$

Th17 cells are a T-cell subset having important roles in inflammatory and autoimmune diseases. ${ }^{63}$ However, their role in tumor pathogenesis and treatment remains controversial. ${ }^{64,65}$ Recently, gemcitabine and 5-FU were shown to activate the inflammasome pathway in MDSCs, leading to IL-1 $\beta$ production, which, in turn, induced IL-17 secretion by CD4 T-cells and blunted the anticancer efficacy of chemotherapy. ${ }^{66}$ In another report, however, optimal anticancer responses during doxorubicin treatment have been shown to require the $\mathrm{IL}-17$-producing $\gamma \delta$ T-cell population. ${ }^{52} \mathrm{~A}$ dosedependent effect on the expansion or differentiation of CD4 Tcells producing IL-17A was also observed in naive and tumorbearing mice following treatment with CTX. ${ }^{67}$ In the same report, it was shown that the levels of IL-17 secretion in PBMCs after $\mathrm{T}$-cell receptor stimulation were significantly enhanced in patients treated with metronomic CTX, with CD4 T-cells being the major source of IL-17. ${ }^{67}$ Nevertheless, whether CTX-induced Th17 contributes to the antitumor efficacy of CTX remains unclear.

\section{Effects on Regulatory Subsets and Pathways}

Besides the active stimulation of effector cells, immunopotentiation by cytotoxic chemotherapy can also be achieved through the inhibition of tumor-induced immune suppression. Several subsets of immunoregulatory cells have been identified so far in cancer patients. ${ }^{68}$ CD4-CD25-expressing Tregs and myeloid cells with suppressive functions, namely MDSCs and TAMs, accumulate in the blood and, especially, within tumor burden, thus contributing to disease progression through various mechanisms. ${ }^{68,69}$

Different strategies to achieve therapeutic depletion of suppressive cell subsets have been described so far. ${ }^{70-72}$ Gemcitabine kills MDSCs, both in vitro and in vivo, ${ }^{49,73}$ with no significant reduction in other cell subsets. The selective loss of MDSCs was accompanied by an increase in the antitumor activity of CD8 $\mathrm{T}$ and NK cells. ${ }^{36}$ Most platinum-based compounds inhibit STAT6-regulated expression of programmed death ligand-2, thus limiting immunosuppression by both DCs and tumor cells. ${ }^{74}$ Low-dose CTX selectively, but transiently, suppresses Tregs ${ }^{43,75,76}$ and impairs the production of immune-suppressive cytokines, such as IL-4, IL-10 and IL-13. ${ }^{41,77}$ A prolonged and more effective Treg inhibition was achieved by metronomic CTX regimens in patients with advanced solid tumors ${ }^{6}$ or with metastatic breast cancer. ${ }^{78}$ Moreover, metronomic temozolomide, an analog of dacarbazine, reduced the number and the suppressive function of circulating Tregs in rats bearing glioma, although it did not restrain tumor growth. ${ }^{79}$

The role of CTX on MDSCs is more controversial. Early reports have supported the concept that CTX induces the development of natural suppressor cells. ${ }^{80-82}$ Increased circulating MDSC frequencies were observed in breast cancer patients and in B16 melanoma-bearing mice injected with CTX plus doxorubicin. ${ }^{83,84}$ Recently, low-dose CTX treatment of mice spontaneously developing melanomas led to an accumulation of inflammatory mediators, such as GM-CSF, IL-1 $\beta$, IL-5, IL-10, IFN- $\gamma$ and TNF- $\alpha$, in skin tumors and metastatic LNs, inducing accumulation and activation of MDSCs that abrogated CTX antitumor effects. ${ }^{85}$ Other reports, however, show that CTX induces early myeloid effector cells that may inhibit tumor cell growth through nitric oxide (NO) release, ${ }^{86}$ and that metronomic CTX plus gemcitabine mitigates Treg- and MDSC-mediated immunosuppression and elicits antitumor immunity in vivo. ${ }^{87}$

Among taxanes, paclitaxel specifically impairs viability and cytokine production in FOXP3 ${ }^{+}$Treg cells, but not in FOXP3 ${ }^{-}$ CD4 effector cells. ${ }^{88}$ Docetaxel, another antimicrotubule agent, was shown to polarize MDSCs toward an M1-like phenotype, and to selectively kill MDSCs while sparing the M1-like cells. ${ }^{89}$ Recently, 5-FU has been shown to selectively induce MDSC apoptosis in vitro and in vivo, ${ }^{49,90}$ resulting in enhanced IFN- $\gamma$ secretion by tumor-infiltrating CD8 T-cells and T-cell-mediated antitumor responses in vivo. ${ }^{90}$

Suppressor cells adopt various means to inhibit the antitumor activity of effector lymphocytes. Some studies suggest that several enzymes, such as arginase I, indoleamine 2, 3-dioxygenase (IDO) and iNOS, as well as surface molecules, such as latency-associated peptide and CD124, are related to immune suppression and tumor progression. ${ }^{68,91}$ Therefore, the effects of chemotherapy on these suppressive mediators also appear to be relevant for rupture of tumor-induced tolerance. A serial analysis of blood samples from advanced non-small cell lung cancer patients treated with platinum-based compounds revealed decreased iNOS, IDO and CD124 expression after chemotherapy. ${ }^{92}$ In contrast, gemcitabine and 5-FU were recently shown to activate immune regulatory cells, which stimulated the emergence of pro-tumorigenic cytokines via inflammasome pathways, thus limiting the therapeutic efficacy of the drugs. ${ }^{66}$

\section{Effects on Tumor Cells and on Tumor Microenvironment}

TCD is the main goal of chemotherapy. Cytotoxic drugs kill tumor cells in different ways and modulate the host immune system accordingly, with consequences that are only now beginning to be elucidated. In addition, there is now evidence that the nature of the immune infiltrate, which often outnumbers neoplastic cells, is relevant for cancer prognosis. ${ }^{93}$ Therefore, changing the composition of the immune infiltrate by anticancer treatments may prove beneficial for cancer elimination. Under defined circumstances, chemotherapyinduced TCD can set the stage for an effective antitumor immune response. For example, some anticancer drugs increase the expression of death receptors, including FAS, TNF receptors and TNF-related apoptosis-inducing ligand receptors. ${ }^{94}$ Other drugs trigger apoptosis by inducing release of cytochrome $c$ from mitochondria. ${ }^{94}$ The degree of TCD correlates with clinical outcome in several tumor settings. ${ }^{95,96}$

Some chemotherapeutics, including anthracyclines, oxaliplatin and CTX, are unique in their capacity to induce an immunogenic type of TCD, ${ }^{21,97}$ thereby converting dying tumor cells into adjuvanted-endogenous vaccines. The 
rational base of vaccination is that tumor antigens must be captured by activated DCs, which would activate CD4 and CD8 T-cell-mediated adaptive immune responses. In an immunogenic type of TCD, antigen is provided by the dying tumor cells in the context of an immunostimulatory environment for DCs. The molecular mechanisms that distinguish immunogenic from non-immunogenic cell death have been elucidated and rely on at least three independent events: (i) early surface exposure of calreticulin (ecto-CRT) on stressed cells, (ii) subsequent secretion of ATP and (iii) release of high-mobility group box-1 (HMGB1) and HSPs by dying tumor cells. ${ }^{1,98}$ Ecto-CRT favors the engulfment of apoptotic bodies by DCs, whereas HMGB1 and ATP modulate DC-mediated tumor antigen cross-presentation and T-cell polarization. Recently, ATP was shown to also mediate the recruitment and differentiation of myeloid DC to the tumor site following anthracycline treatment in mice. ${ }^{99}$ Exposure of human colon carcinoma cells to a multidrug regimen, including gemcitabine, oxaliplatin, leucovorin and 5-FU induced high levels of tumor necrosis and apoptosis that activated DC cross-presentation and stimulated potent antigen-specific CTL responses in vitro. ${ }^{100}$ Similarly to anthracyclines, some alkylating agents have also been shown to induce an immunogenic TCD that stimulates antigen cross-presentation by DC, and CD8 T-cell crosspriming. ${ }^{21,101}$

Seldom, non-apoptotic death pathways are also induced by chemotherapy with mechanisms that are now beginning to be explained. Some alkylating agents (nitrogen mustard and $\mathrm{N}$-methyl-N-nitro-N-nitrosoguanidine) induce necrosis, an unregulated process rising from acute cellular stress or massive cell injury. ${ }^{102}$ Unlike apoptosis, necrosis is intrinsically immunogenic due to the immediate release of proinflammatory mediators, such as IL-8, IL-10, TNF- $\alpha$ and HMGB1. ${ }^{102}$ Paclitaxel induces mitotic catastrophe, a type of cell death that occurs as a consequence of failed mitosis. ${ }^{102}$ Tumor cells undergoing mitotic catastrophe often have checkpoint deficiencies that result in incomplete DNA repair, replicative infidelity and chromosomal desegregation. ${ }^{103}$ The immunogenic potential of tumor cells dying by mitotic catastrophe has not been fully clarified.

A number of antineoplastic therapies were shown to induce autophagy in human cancer cells. ${ }^{104}$ However, whether autophagy contributes to TCD after cytotoxic therapy or represents a mechanism of resistance is still a matter of debate. During unfavorable metabolic conditions (for example, cell stress/damage by cytotoxic compounds), apoptosisdefective tumor cells can survive by invoking a protective autophagic process, that is, degradation of proteins and organelles to provide amino acids, fatty acids and nucleotides for reuse. ${ }^{102,104}$ Some findings suggest that prolonged stimulation of autophagy may be detrimental to cancer cells and that therapies that inhibit autophagy may lead to enhanced tumor growth. ${ }^{105}$ Other studies, however, support the use of autophagy inhibitors as potentiators of anticancer agents. ${ }^{106,107}$ As an example, the mammalian target of rapamycin (mTOR) kinase inhibitor everolimus, which induces autophagy, prolonged the survival of patients affected by renal cell carcinoma in a phase-III clinical trial. ${ }^{106}$ Interestingly, Michaud et al. ${ }^{108}$ reported that autophagy is dispensable for chemotherapy-induced TCD, but is required for its immunogenicity. ${ }^{108}$ These findings imply that only patients bearing autophagy-competent cancers might benefit from immunogenic chemotherapy.

Chemotherapy can also render cancer cells more susceptible to CTL and NK-cell killing. 5-FU, irinotecan and cisplatin were all shown to increase the sensitivity of the SW480 colon cancer cell line to CTLs. ${ }^{109}$ Paclitaxel, cisplatin and doxorubicin sensitize tumor cells to CTLs by rendering them permeable to granzyme B via upregulation of mannose-6phosphate receptors on tumor cell surface. ${ }^{110}$ Furthermore, CTX sensitizes tumor cells to TRAIL-dependent CD8 T-cellmediated immune attack, ${ }^{111}$ suggesting that TRAIL-mediated tumor cell killing contributes to immunogenic TCD. ${ }^{112}$ Platinum derivatives and dacarbazine were shown to stimulate the expression of ligands for NKG2D, an NK cellactivating receptor, resulting in augmented NK-cell cytotoxicity and IFN- $\gamma$ production. ${ }^{113}$ Numerous agents promote functional downregulation of the inhibitory NK ligand Clr-b and upregulation of stimulatory NKG2D ligand on tumor cells, thus enhancing the susceptibility of target cells to NK cellmediated lysis. ${ }^{114}$ Interestingly, gemcitabine has been shown to increase the expression of HLA on malignant cells, ${ }^{115}$ and to enhance the cross-presentation of tumor antigens to CD8 T-cells. ${ }^{115,116}$ Similarly, combined $5-\mathrm{FU} / \mathrm{IFN}-\alpha$ treatment increased the expression of $\mathrm{MHC}$ class I and NKG2D ligands on murine pancreatic tumor cells. ${ }^{9}$ In another study, low-dose chemotherapy triggered the expression of ligands for NKG2D and DNAM-1 on multiple myeloma, and promoted NK-cell degranulation against tumor. ${ }^{117}$

\section{Other Off-Target, Non-Immune-Based Effects of Chemotherapy}

Myelosuppression, which develops after cytotoxic chemotherapy, represents the major toxic side effect of cancer treatment, thus limiting its use. As the BM contains the most mitotically active cells in the organism, it becomes a preferential target for chemotherapy-induced cytotoxicity. However, it is now becoming clearer that not all side effects of cytotoxic chemotherapy are necessarily harmful. Genomewide expression analysis of different tissue samples from CTX-treated tumor-bearing animals revealed the occurrence of an immunogenic apoptosis not only in tumor cells but also in BM and spleen cells, which paralleled with activation of bystander inflammatory responses. ${ }^{43}$

Moreover, the drug type and dosage crucially dictate the outcome of drug-induced cytotoxicity. For example, it has been reported that CTX and 5-FU are less damaging for most primitive cells than other cytotoxic drugs. ${ }^{118}$ Furthermore, although high-dose CTX kills BM-resident DC precursors, thus hampering DC mobilization at the peripheral level, ${ }^{119,120}$ these precursors are resistant to low-dose CTX, which instead boosts the differentiation of mature DCs in vivo and ex vivo. ${ }^{21,121,122}$ Of note, CTX-induced mobilization and maturation of DCs from their BM precursors was mediated by endogenous type I IFN. ${ }^{21,55,123}$

Other non-immune targets of cytotoxic chemotherapy are the endothelial cells. Indeed, the collateral damage inflicted upon dividing endothelial cells within the tumor bed indirectly 
helps tumor destruction. ${ }^{124}$ Moreover, the majority of anticancer drugs can inhibit angiogenesis. ${ }^{125}$ Low-dose CTX exhibits antiangiogenic activity by killing circulating endothelial progenitors ${ }^{126}$ and decreasing NO concentrations in serum. ${ }^{127}$ A more comprehensive and integrated understanding of the multifaceted off-target effects of cytotoxic drugs may help designing more efficacious combined treatments while avoiding ineffective or possibly antagonistic combinations.

\section{Implications for Combination with Other Treatments}

The observations reported above have several implications for planning future clinical trials combining chemotherapy with immunotherapy. First, cytotoxic agents that elicit immunogenic TCD, which converts the tumor itself into an endogenous vaccine and provides adequate DC stimulation, through release of danger signals, are ideal candidates for combination with adoptive immunotherapy strategies aimed at eliminating immune suppressor cells. For example, combining standard chemotherapy with ipilimumab, a human anti-CTLA-4 monoclonal antibody that blocks the CTLA-4 inhibitory signal on T-cells, proved extremely effective in a phase-III clinical trial on advanced melanoma patients, ${ }^{128,129}$ as well as in a phase-II clinical trial on lung cancer patients. ${ }^{130}$ Second, as chemotherapy increases the immune visibility of surviving or damaged tumor cells by upregulating HLA molecules and NK-related or TRAIL ligands, co-administration of immunostimulatory molecules (for example, TLR ligands, cytokines, and so on) may further facilitate immune recognition by DCs and NK, thus potentiating antitumor T-cell responses. As type I IFN enhances the cross-presentation of tumor-derived antigens by DCs ${ }^{131}$ and synergizes with CTX when injected intratumorally, ${ }^{21}$ these cytokines are attractive candidates to be combined with chemotherapy. Third, the selective depletion of inhibitory subsets by some anticancer drugs (for example, CTX or gemcitabine) or regimens (for example, metronomic) provides the optimal setting for combination, with active vaccination strategies aimed at expanding the already existing tumor-reactive immune responses. In this respect, several targeted compounds such as imatinib (an IDO inhibitor), sunitinib (MDSC and Treg antagonist) are also gaining applicability. ${ }^{132}$ Fourth, some agents exert bystander effects on the host, which are crucially required for synergism with active or adoptive immunotherapy. ${ }^{33}$ In all cases, the time-window for optimal combination must be carefully considered. Data obtained in both animal models and humans suggest that immunotherapy should immediately follow chemotherapy (1-2 days interval) to achieve the best synergism between the two treatments. ${ }^{33}$

\section{Conclusions}

It is now becoming evident that standard chemotherapy agents can deeply have an impact on both tumor and host immune system. Although to our knowledge no systematic analysis has been carried out to evaluate differences in the immune-based effects of conventional chemotherapeutic agents depending on cancer histology or stage, it is now clear that the existence of tumor-host interplay dictates the magnitude, quality and efficacy of most anticancer strategies. Advances in tumor immunology have now undisclosed some key mechanisms that represent the basis of therapeutic synergy or of antagonism with other treatments. The ensemble of results discussed herein contributes to pave the way towards mechanism-based, rather than empirical, rationales for combination of specific chemotherapeutic agents with selective immunotherapeutic interventions, opening novel horizons for more effective management of cancer patients.

\section{Conflict of Interest}

The authors declare no conflict of interest.

Acknowledgements. This work was supported by grants from the Italian Association for Research against Cancer (AIRC) to LB, FB and LG. We wish to thank Mrs. Rosina Bellizzi and Mr Teodoro Squatriti for secretarial and technical assistance.

1. Apetoh L, Ghiringhelli F, Tesniere A, Obeid M, Ortiz C, Criollo A et al. Toll-like receptor 4-dependent contribution of the immune system to anticancer chemotherapy and radiotherapy. Nat Med 2007; 13: 1050-1059.

2. Mackay IR, Goodyear MD, Riglar C, Penschow J. Effect on natural killer and antibodydependent cellular cytotoxicity of adjuvant cytotoxic chemotherapy including melphalan in breast cancer. Cancer Immunol Immunother 1983; 16: 98-100.

3. Braun DP, Harris JE. Effect of chemotherapy on NK function in the peripheral blood of cancer patients. Cancer Immunol Immunother 1986; 21: 240-245.

4. Brenner BG, Margolese RG. The relationship of chemotherapeutic and endocrine intervention on natural killer cell activity in human breast cancer. Cancer 1991; 68: 482-488.

5. Sewell HF, Halbert CF, Robins RA, Galvin A, Chan S, Blamey RW. Chemotherapyinduced differential changes in lymphocyte subsets and natural-killer-cell function in patients with advanced breast cancer. Int J Cancer 1993; 55: 735-738.

6. Ghiringhelli F, Menard C, Puig PE, Ladoire S, Roux S, Martin F et al. Metronomic cyclophosphamide regimen selectively depletes CD4 + CD25 + regulatory T-cells and restores T and NK effector functions in end stage cancer patients. Cancer Immunol Immunother 2007; 56: 641-648.

7. Liu P, Jaffar J, Hellstrom I, Hellstrom KE. Administration of cyclophosphamide changes the immune profile of tumor-bearing mice. J Immunother 2010; 33: 53-59.

8. Doloff JC, Waxman DJ. VEGF receptor inhibitors block the ability of metronomically dosed cyclophosphamide to activate innate immunity-induced tumor regression. Cancer Res 2012; 72: 1103-1115

9. Khallouf H, Marten A, Serba S, Teichgraber V, Buchler MW, Jager D et al. 5-Fluorouracil and interferon-alpha immunochemotherapy enhances immunogenicity of murine pancreatic cancer through upregulation of NKG2D ligands and MHC class I. J Immunother 2012; 35: 245-253.

10. Martinez FO, Sica A, Mantovani A, Locati M. Macrophage activation and polarization. Front Biosci 2008; 13: 453-461.

11. Mills CD, Kincaid K, Alt JM, Heilman MJ, Hill AM. M-1/M-2 macrophages and the Th1/Th2 paradigm. J Immunol 2000; 164: 6166-6173.

12. Heusinkveld M, van der Burg SH. Identification and manipulation of tumor associated macrophages in human cancers. J Transl Med 2011; 9: 216.

13. Bryniarski K, Szczepanik M, Ptak M, Zemelka M, Ptak W. Influence of cyclophosphamide and its metabolic products on the activity of peritoneal macrophages in mice. Pharmacol Rep 2009; 61: 550-557.

14. Buhtoiarov IN, Sondel PM, Wigginton JM, Buhtoiarova TN, Yanke EM, Mahvi DA et al. Anti-tumour synergy of cytotoxic chemotherapy and anti-CD40 plus CpG-ODN immunotherapy through repolarization of tumour-associated macrophages. Immunology 2011; 132: 226-239.

15. Potapov SL, Korman DB, Shamaev VI, Ershova RB, Makarov OV. Sensitivity of clonogenic cells of human ovarian ascitic cancer to antitumor drugs. Arch Geschwulstforsch 1988; 58: 99-104.

16. Park S, Kang S, Chen X, Kim EJ, Kim J, Kim N et al. Tumor suppression via paclitaxelloaded drug carriers that target inflammation marker upregulated in tumor vasculature and macrophages. Biomaterials 2013; 34: 598-605.

17. Javeed A, Ashraf M, Riaz A, Ghafoor A, Afzal S, Mukhtar MM. Paclitaxel and immune system. Eur J Pharm Sci 2009; 38: 283-290.

18. DeNardo DG, Brennan DJ, Rexhepaj E, Ruffell B, Shiao SL, Madden SF et al. Leukocyte complexity predicts breast cancer survival and functionally regulates response to chemotherapy. Cancer Discov 2011; 1: 54-67. 
19. Shree T, Olson OC, Elie BT, Kester JC, Garfall AL, Simpson K et al. Macrophages and cathepsin proteases blunt chemotherapeutic response in breast cancer. Genes Dev 2011; 25: 2465-2479.

20. Nakahara T, Uchi H, Lesokhin AM, Avogadri F, Rizzuto GA, Hirschhorn-Cymerman D et al. Cyclophosphamide enhances immunity by modulating the balance of dendritic cell subsets in lymphoid organs. Blood 2010; 115: 4384-4392.

21. Schiavoni G, Sistigu A, Valentini M, Mattei F, Sestili P, Spadaro F et al. Cyclophosphamide synergizes with type I interferons through systemic dendritic cell reactivation and induction of immunogenic tumor apoptosis. Cancer Res 2011; 71: 768-778.

22. Chen J, Huang X, Huang G, Chen Y, Chen L, Song H. Preconditioning chemotherapy with cisplatin enhances the antitumor activity of cytokine-induced killer cells in a murine melanoma model. Cancer Biother Radiopharm 2012; 27: 210-220.

23. Soeda A, Morita-Hoshi Y, Makiyama H, Morizane C, Ueno H, Ikeda M et al. Regular dose of gemcitabine induces an increase in CD14 + monocytes and CD11c + dendritic cells in patients with advanced pancreatic cancer. Jpn J Clin Oncol 2009; 39: 797-806.

24. Tanaka H, Matsushima H, Mizumoto N, Takashima A. Classification of chemotherapeutic agents based on their differential in vitro effects on dendritic cells. Cancer Res 2009; 69 : 6978-6986.

25. Shurin GV, Tourkova IL, Kaneno R, Shurin MR. Chemotherapeutic agents in noncytotoxic concentrations increase antigen presentation by dendritic cells via an IL-12-dependen mechanism. J Immunol 2009; 183: 137-144.

26. Kaneno R, Shurin GV, Tourkova IL, Shurin MR. Chemomodulation of human dendritic cell function by antineoplastic agents in low noncytotoxic concentrations. J Transl Med 2009; 7: 58

27. Tanaka H, Matsushima H, Nishibu A, Clausen BE, Takashima A. Dual therapeutic efficacy of vinblastine as a unique chemotherapeutic agent capable of inducing dendritic cell maturation. Cancer Res 2009; 69: 6987-6994.

28. Wehner R, Bitterlich A, Meyer N, Kloss A, Schakel K, Bachmann M et al. Impact of chemotherapeutic agents on the immunostimulatory properties of human 6-sulfo LacNAc + (slan) dendritic cells. Int J Cancer 2013; 132: 1351-1359.

29. Buttiglieri S, Galetto A, Forno S, De Andrea M, Matera L. Influence of drug-induced apoptotic death on processing and presentation of tumor antigens by dendritic cells. Int J Cancer 2003; 106: 516-520.

30. Galetto A, Buttiglieri S, Forno S, Moro F, Mussa A, Matera L. Drug- and cell-mediated antitumor cytotoxicities modulate cross-presentation of tumor antigens by myeloid dendritic cells. Anticancer Drugs 2003; 14: 833-843.

31. Casares N, Pequignot MO, Tesniere A, Ghiringhelli F, Roux S, Chaput N et al. Caspasedependent immunogenicity of doxorubicin-induced tumor cell death. J Exp Med 2005 202: 1691-1701.

32. Mackall CL, Fleisher TA, Brown MR, Magrath IT, Shad AT, Horowitz ME et al. Lymphocyte depletion during treatment with intensive chemotherapy for cancer. Blood 1994: 84: 2221-2228.

33. Proietti E, Moschella F, Capone I, Belardelli F. Exploitation of the propulsive force of chemotherapy for improving the response to cancer immunotherapy. Mol Oncol 2012; 6 : $1-14$

34. Wijayahadi N, Haron MR, Stanslas J, Yusuf Z. Changes in cellular immunity during chemotherapy for primary breast cancer with anthracycline regimens. J Chemother 2007 19: $716-723$.

35. Nowak AK, Robinson BW, Lake RA. Gemcitabine exerts a selective effect on the humoral immune response: implications for combination chemo-immunotherapy. Cancer Res 2002; 62: 2353-2358

36. Suzuki E, Kapoor V, Jassar AS, Kaiser LR, Albelda SM. Gemcitabine selectively eliminates splenic Gr-1 +/CD11b + myeloid suppressor cells in tumor-bearing animals and enhances antitumor immune activity. Clin Cancer Res 2005; 11: 6713-6721.

37. Shebzukhov YV, Koroleva EP, Khlgatian SV, Lagarkova MA, Meshcheryakov AA, Lichinitser MR et al. Humoral immune response to thymidylate synthase in colon cancer patients after 5-FU chemotherapy. Immunol Lett 2005; 100: 88-93.

38. Otterness IG, Chang YH. Comparative study of cyclophosphamide, 6-mercaptopurine azathiopurine and methotrexate. Relative effects on the humoral and the cellular immune response in the mouse. Clin Exp Immunol 1976; 26: 346-354

39. Smith SR, Terminelli C, Kipilman CT, Smith Y. Comparative effects of azathioprine cyclophosphamide and frentizole on cellular immunity in mice. J Immunopharmacol 1981 3: $133-170$.

40. Berd D, Maguire HC Jr, Mastrangelo MJ. Potentiation of human cell-mediated and humoral immunity by low-dose cyclophosphamide. Cancer Res 1984; 44: 5439-5443.

41. Bracci L, Moschella F, Sestili P, La Sorsa V, Valentini M, Canini I et al. Cyclophosphamide enhances the antitumor efficacy of adoptively transferred immune cells through the induction of cytokine expression, B-cell and T-cell homeostatic proliferation, and specific tumor infiltration. Clin Cancer Res 2007; 13: 644-653.

42. Proietti E, Greco G, Garrone B, Baccarini S, Mauri C, Venditti M et al. Importance of cyclophosphamide-induced bystander effect on T-cells for a successful tumor eradication in response to adoptive immunotherapy in mice. J Clin Invest 1998; 101: 429-441.

43. Moschella F, Valentini M, Arico E, Macchia I, Sestili P, D'Urso MT et al. Unraveling cancer chemoimmunotherapy mechanisms by gene and protein expression profiling of responses to cyclophosphamide. Cancer Res 2011; 71: 3528-3539.

44. Brzostek-Racine S, Gordon C, Van Scoy S, Reich NC. The DNA damage response induces IFN. J Immunol 2011; 187: 5336-5345.
45. Li Q, Teitz-Tennenbaum S, Donald EJ, Li M, Chang AE. In vivo sensitized and in vitro activated $B$ cells mediate tumor regression in cancer adoptive immunotherapy. $\mathrm{J}$ Immunol 2009; 183: 3195-3203.

46. Montero E, Valdes M, Avellanet J, Lopez A, Perez R, Lage A. Chemotherapy induced transient B-cell depletion boosts antibody-forming cells expansion driven by an epidermal growth factor-based cancer vaccine. Vaccine 2009; 27: 2230-2239.

47. Kim JE, Jang MJ, Lee Jl, Chung YH, Jeong JH, Hung CF et al. Cancer cells containing nanoscale chemotherapeutic drugs generate antiovarian cancer-specific CD4 + T-cells in peritoneal space. J Immunother 2012; 35: 1-13.

48. Chang CL, Hsu YT, Wu CC, Lai YZ, Wang C, Yang YC et al. Dose-dense chemotherapy improves mechanisms of antitumor immune response. Cancer Res 2013; 73: 119-127.

49. Vincent J, Mignot G, Chalmin F, Ladoire S, Bruchard M, Chevriaux A et al. 5-Fluorouracil selectively kills tumor-associated myeloid-derived suppressor cells resulting in enhanced T-cell-dependent antitumor immunity. Cancer Res 2010; 70: 3052-3061.

50. Predina JD, Judy B, Aliperti LA, Fridlender ZG, Blouin A, Kapoor V et al. Neoadjuvant in situ gene-mediated cytotoxic immunotherapy improves postoperative outcomes in novel syngeneic esophageal carcinoma models. Cancer Gene Ther 2011; 18: 871-883.

51. Tsuchikawa T, Md MM, Yamamura Y, Shichinohe T, Hirano S, Kondo S. The immunological impact of neoadjuvant chemotherapy on the tumor microenvironment of esophageal squamous cell carcinoma. Ann Surg Oncol 2012; 19: 1713-1719.

52. Mattarollo SR, Loi S, Duret H, Ma Y, Zitvogel L, Smyth MJ. Pivotal role of innate and adaptive immunity in anthracycline chemotherapy of established tumors. Cancer Res 2011; 71: 4809-4820.

53. Rosenberg SA, Spiess $P$, Lafreniere R. A new approach to the adoptive immunotherapy of cancer with tumor-infiltrating lymphocytes. Science 1986; 233: 1318-1321.

54. Vierboom MP, Bos GM, Ooms M, Offringa R, Melief CJ. Cyclophosphamide enhances anti-tumor effect of wild-type p53-specific CTL. Int J Cancer 2000; 87: 253-260.

55. Schiavoni G, Mattei F, Di Pucchio T, Santini SM, Bracci L, Belardelli F et al. Cyclophosphamide induces type I interferon and augments the number of CD44(hi) $T$ lymphocytes in mice: implications for strategies of chemoimmunotherapy of cancer. Blood 2000; 95: 2024-2030.

56. Ding ZC, Blazar BR, Mellor AL, Munn DH, Zhou G. Chemotherapy rescues tumor-driven aberrant CD4 + T-cell differentiation and restores an activated polyfunctional helper phenotype. Blood 2010; 115: 2397-2406.

57. Boissonnas A, Licata F, Poupel L, Jacquelin S, Fetler L, Krumeich S et al. CD8 + tumorinfiltrating T-cells are trapped in the tumor-dendritic cell network. Neoplasia 2013; 15: 85-94.

58. Kim YH, Choi BK, Oh HS, Kang WJ, Mittler RS, Kwon BS. Mechanisms involved in synergistic anticancer effects of anti-4-1BB and cyclophosphamide therapy. Mol Cancer Ther 2009; 8: 469-478.

59. Nistico P, Capone I, Palermo B, Del Bello D, Ferraresi V, Moschella F et al. Chemotherapy enhances vaccine-induced antitumor immunity in melanoma patients. Int J Cancer 2009; 124: 130-139.

60. Palermo B, Del Bello D, Sottini A, Serana F, Ghidini C, Gualtieri N et al. Dacarbazine treatment before peptide vaccination enlarges $\mathrm{T}$-cell repertoire diversity of melan-aspecific, tumor-reactive CTL in melanoma patients. Cancer Res 2010; 70: 7084-7092.

61. Zhang L, Dermawan K, Jin M, Liu R, Zheng H, Xu L et al. Differential impairment of regulatory $\mathrm{T}$-cells rather than effector T-cells by paclitaxel-based chemotherapy. Clin Immunol 2008; 129: 219-229.

62. Matar P, Rozados VR, Gervasoni SI, Scharovsky GO. Th2/Th1 switch induced by a single low dose of cyclophosphamide in a rat metastatic lymphoma model. Cancer Immunol Immunother 2002; 50: 588-596.

63. Ghoreschi K, Laurence A, Yang XP, Hirahara K, O'Shea JJ. T helper 17 cell heterogeneity and pathogenicity in autoimmune disease. Trends Immunol 2011; 32 : 395-401.

64. Iwakura $\mathrm{Y}$, Ishigame $\mathrm{H}$, Saijo $\mathrm{S}$, Nakae $\mathrm{S}$. Functional specialization of interleukin-17 family members. Immunity 2011; 34: 149-162.

65. Kryczek I, Wei S, Szeliga W, Vatan L, Zou W. Endogenous IL-17 contributes to reduced tumor growth and metastasis. Blood 2009; 114: 357-359.

66. Bruchard M, Mignot G, Derangere V, Chalmin F, Chevriaux A, Vegran F et al. Chemotherapy-triggered cathepsin $B$ release in myeloid-derived suppressor cells activates the Nlrp3 inflammasome and promotes tumor growth. Nat Med 2013; 19: 57-64.

67. Viaud S, Flament C, Zoubir M, Pautier P, LeCesne A, Ribrag V et al. Cyclophosphamide induces differentiation of Th17 cells in cancer patients. Cancer Res 2011:71: 661-665.

68. Poschke I, Mougiakakos D, Kiessling R. Camouflage and sabotage: tumor escape from the immune system. Cancer Immunol Immunother 2011; 60: 1161-1171.

69. Mantovani A, Sica A, Allavena P, Garlanda C, Locati M. Tumor-associated macrophages and the related myeloid-derived suppressor cells as a paradigm of the diversity of macrophage activation. Hum Immunol 2009; 70: 325-330.

70. Onizuka S, Tawara I, Shimizu J, Sakaguchi S, Fujita T, Nakayama E. Tumor rejection by in vivo administration of anti-CD25 (interleukin-2 receptor alpha) monoclonal antibody. Cancer Res 1999; 59: 3128-3133.

71. Sutmuller RP, van Duivenvoorde LM, van Elsas A, Schumacher TN, Wildenberg ME, Allison JP et al. Synergism of cytotoxic T lymphocyte-associated antigen 4 blockade and depletion of $\mathrm{CD} 25(+)$ regulatory T-cells in antitumor therapy reveals alternative pathways for suppression of autoreactive cytotoxic T lymphocyte responses. J Exp Med 2001; 194: 823-832. 
72. Najjar YG, Finke JH. Clinical perspectives on targeting of myeloid derived suppressor cells in the treatment of cancer. Front Oncol 2013; 3: 49.

73. Mundy-Bosse BL, Lesinski GB, Jaime-Ramirez AC, Benninger K, Khan M, Kuppusamy $P$ et al. Myeloid-derived suppressor cell inhibition of the IFN response in tumor-bearing mice. Cancer Res 2011; 71: 5101-5110.

74. Lesterhuis WJ, Punt CJ, Hato SV, Eleveld-Trancikova D, Jansen BJ, Nierkens S et al. Platinum-based drugs disrupt STAT6-mediated suppression of immune responses against cancer in humans and mice. J Clin Invest 2011; 121: 3100-3108.

75. Ghiringhelli F, Menard C, Terme M, Flament C, Taieb J, Chaput N et al. CD4 + CD25 + regulatory T-cells inhibit natural killer cell functions in a transforming growth factor-betadependent manner. J Exp Med 2005; 202: 1075-1085.

76. Lutsiak ME, Semnani RT, De Pascalis R, Kashmiri SV, Schlom J, Sabzevari H. Inhibition of $\mathrm{CD} 4(+) 25+\mathrm{T}$ regulatory cell function implicated in enhanced immune response by low-dose cyclophosphamide. Blood 2005; 105: 2862-2868.

77. Guerriero JL, Ditsworth D, Catanzaro JM, Sabino G, Furie MB, Kew RR et al. DNA alkylating therapy induces tumor regression through an HMGB1-mediated activation of innate immunity. J Immunol 2011; 186: 3517-3526.

78. Ge Y, Domschke C, Stoiber N, Schott S, Heil J, Rom J et al. Metronomic cyclophosphamide treatment in metastasized breast cancer patients: immunological effects and clinical outcome. Cancer Immunol Immunother 2012; 61: 353-362.

79. Banissi C, Ghiringhelli F, Chen L, Carpentier AF. Treg depletion with a low-dose metronomic temozolomide regimen in a rat glioma model. Cancer Immunol Immunother 2009; 58: 1627-1634.

80. Brooks-Kaiser JC, Bourque LA, Hoskin DW. Heterogeneity of splenic natural suppressor cells induced in mice by treatment with cyclophosphamide. Immunopharmacology 1993; 25: $117-129$.

81. Nikcevich DA, Duffie GP, Young MR, Ellis NK, Kaufman GE, Wepsic HT. Stimulation of suppressor cells in the bone marrow and spleens of high dose cyclophosphamide-treated C57BI/6 mice. Cell Immunol 1987; 109: 349-359.

82. Segre M, Tomei E, Segre D. Cyclophosphamide-induced suppressor cells in mice: suppression of the antibody response in vitro and characterization of the effector cells. Cell Immunol 1985; 91: 443-454.

83. Diaz-Montero CM, Salem ML, Nishimura MI, Garrett-Mayer E, Cole DJ, Montero AJ. Increased circulating myeloid-derived suppressor cells correlate with clinical cancer stage, metastatic tumor burden, and doxorubicin-cyclophosphamide chemotherapy. Cancer Immunol Immunother 2009; 58: 49-59.

84. Salem ML, Al-Khami AA, El-Naggar SA, Diaz-Montero CM, Chen Y, Cole DJ. Cyclophosphamide induces dynamic alterations in the host microenvironments resulting in a Flt3 ligand-dependent expansion of dendritic cells. J Immunol 2010; 184: 1737-1747.

85. Sevko A, Sade-Feldman M, Kanterman J, Michels T, Falk CS, Umansky L et al. Cyclophosphamide Promotes chronic inflammation-dependent immunosuppression and prevents antitumor response in melanoma. J Invest Dermatol 2012; 133: 1610-1619.

86. Pelaez B, Campillo JA, Lopez-Asenjo JA, Subiza JL. Cyclophosphamide induces the development of early myeloid cells suppressing tumor cell growth by a nitric oxidedependent mechanism. J Immunol 2001; 166: 6608-6615.

87. Tongu M, Harashima N, Monma H, Inao T, Yamada T, Kawauchi H et al. Metronomic chemotherapy with low-dose cyclophosphamide plus gemcitabine can induce anti-tumor T-cell immunity in vivo. Cancer Immunol Immunother 2012; 62: 383-391.

88. Zhu Y, Liu N, Xiong SD, Zheng YJ, Chu YW. CD4 ${ }^{+}$Foxp3 ${ }^{+}$regulatory T-cell impairment by paclitaxel is independent of toll-like receptor 4. Scand J Immunol 2011; 73: 301-308.

89. Kodumudi KN, Woan K, Gilvary DL, Sahakian E, Wei S, Djeu JY. A novel chemoimmunomodulating property of docetaxel: suppression of myeloid-derived suppressor cells in tumor bearers. Clin Cancer Res 2010; 16: 4583-4594.

90. Apetoh L, Vegran F, Ladoire S, Ghiringhelli F. Restoration of antitumor immunity through selective inhibition of myeloid derived suppressor cells by anticancer therapies. Curr Mol Med 2011; 11: 365-372.

91. Gabrilovich DI, Ostrand-Rosenberg S, Bronte V. Coordinated regulation of myeloid cells by tumours. Nat Rev Immunol 2012; 12: 253-268.

92. Sim SH, Ahn YO, Yoon J, Kim TM, Lee SH, Kim DW et al. Influence of chemotherapy on nitric oxide synthase, indole-amine-2,3-dioxygenase and CD124 expression in granulocytes and monocytes of non-small cell lung cancer. Cancer Sci 2012; 103: 155-160.

93. Fridman WH, Galon J, Pages F, Tartour E, Sautes-Fridman C, Kroemer G. Prognostic and predictive impact of intra- and peritumoral immune infiltrates. Cancer Res 2011; 71: 5601-5605.

94. Lake RA, Robinson BW. Immunotherapy and chemotherapy-a practical partnership. Nat Rev Cancer 2005; 5: 397-405.

95. Cassinelli G, Supino R, Perego P, Polizzi D, Lanzi C, Pratesi G et al. A role for loss of p53 function in sensitivity of ovarian carcinoma cells to taxanes. Int J Cancer 2001; 92: 738-747.

96. Salomons GS, Smets LA, Verwijs-Janssen M, Hart AA, Haarman EG, Kaspers GJ et al. Bcl-2 family members in childhood acute lymphoblastic leukemia: relationships with features at presentation, in vitro and in vivo drug response and long-term clinical outcome. Leukemia 1999; 13: 1574-1580.

97. Galluzzi L, Senovilla L, Zitvogel L, Kroemer G. The secret ally: immunostimulation by anticancer drugs. Nat Rev Drug Discov 2012; 11: 215-233.

98. Tesniere A, Schlemmer F, Boige V, Kepp O, Martins I, Ghiringhelli F et al. Immunogenic death of colon cancer cells treated with oxaliplatin. Oncogene 2010; 29: 482-491.
99. Ma Y, Adjemian S, Mattarollo SR, Yamazaki T, Aymeric L, Yang H et al. Anticancer chemotherapy-induced intratumoral recruitment and differentiation of antigen-presenting cells. Immunity 2013; 38: 729-741.

100. Correale P, Cusi MG, Del Vecchio MT, Aquino A, Prete SP, Tsang KY et al. Dendritic cellmediated cross-presentation of antigens derived from colon carcinoma cells exposed to a highly cytotoxic multidrug regimen with gemcitabine, oxaliplatin, 5-fluorouracil, and leucovorin, elicits a powerful human antigen-specific CTL response with antitumor activity in vitro. J Immunol 2005; 175: 820-828.

101. Kim TG, Kim CH, Park JS, Park SD, Kim CK, Chung DS et al. Immunological factors relating to the antitumor effect of temozolomide chemoimmunotherapy in a murine glioma model. Clin Vaccine Immunol 2010; 17: 143-153.

102. Kepp O, Tesniere A, Schlemmer F, Michaud M, Senovilla L, Zitvogel L et al. Immunogenic cell death modalities and their impact on cancer treatment. Apoptosis 2009; 14: 364-375.

103. Vitale I, Galluzzi L, Castedo M, Kroemer G. Mitotic catastrophe: a mechanism for avoiding genomic instability. Nat Rev Mol Cell Biol 2011; 12: 385-392.

104. Apel A, Zentgraf H, Buchler MW, Herr I. Autophagy-A double-edged sword in oncology. Int J Cancer 2009; 125: 991-995.

105. Yu L, Alva A, Su H, Dutt P, Freundt E, Welsh S et al. Regulation of an ATG7-beclin 1 program of autophagic cell death by caspase-8. Science 2004; 304: 1500-1502.

106. Agarwala SS, Case S. Everolimus (RAD001) in the treatment of advanced renal cell carcinoma: a review. Oncologist 2010; 15: 236-245.

107. Amaravadi RK, Yu D, Lum JJ, Bui T, Christophorou MA, Evan Gl et al. Autophagy inhibition enhances therapy-induced apoptosis in a Myc-induced model of lymphoma. $J$ Clin Invest 2007; 117: 326-336.

108. Michaud M, Martins I, Sukkurwala AQ, Adjemian S, Ma Y, Pellegatti P et al. Autophagydependent anticancer immune responses induced by chemotherapeutic agents in mice. Science 2011; 334: 1573-1577.

109. Bergmann-Leitner ES, Abrams SI. Treatment of human colon carcinoma cell lines with anti-neoplastic agents enhances their lytic sensitivity to antigen-specific CD8 + cytotoxic T Iymphocytes. Cancer Immunol Immunother 2001; 50: 445-455.

110. Ramakrishnan R, Assudani D, Nagaraj S, Hunter T, Cho HI, Antonia S et al. Chemotherapy enhances tumor cell susceptibility to CTL-mediated killing during cancer immunotherapy in mice. J Clin Invest 2010; 120: 1111-1124.

111. van der Most RG, Currie AJ, Cleaver AL, Salmons J, Nowak AK, Mahendran S et al. Cyclophosphamide chemotherapy sensitizes tumor cells to TRAIL-dependent CD8 T-cellmediated immune attack resulting in suppression of tumor growth. PLoS One 2009; 4: e6982.

112. Ullrich E, Bonmort M, Mignot G, Jacobs B, Bosisio D, Sozzani S et al. Trans-presentation of IL-15 dictates IFN-producing killer dendritic cells effector functions. J Immunol 2008; 180: 7887-7897.

113. Gasser S, Orsulic S, Brown EJ, Raulet DH. The DNA damage pathway regulates innate immune system ligands of the NKG2D receptor. Nature 2005; 436: 1186-1190.

114. Fine JH, Chen P, Mesci A, Allan DS, Gasser S, Raulet DH et al. Chemotherapy-induced genotoxic stress promotes sensitivity to natural killer cell cytotoxicity by enabling missingself recognition. Cancer Res 2010; 70: 7102-7113.

115. Liu WM, Fowler DW, Smith P, Dalgleish AG. Pre-treatment with chemotherapy can enhance the antigenicity and immunogenicity of tumours by promoting adaptive immune responses. Br J Cancer 2010; 102: 115-123.

116. Nowak AK, Lake RA, Marzo AL, Scott B, Heath WR, Collins EJ et al. Induction of tumor cell apoptosis in vivo increases tumor antigen cross-presentation, cross-priming rathe than cross-tolerizing host tumor-specific CD8 T-cells. J Immunol 2003; 170: 4905-4913.

117. Soriani A, Zingoni A, Cerboni C, lannitto ML, Ricciardi MR, Di Gialleonardo V et al. ATMATR-dependent up-regulation of DNAM-1 and NKG2D ligands on multiple myeloma cells by therapeutic agents results in enhanced NK-cell susceptibility and is associated with a senescent phenotype. Blood 2009; 113: 3503-3511.

118. Botnick LE, Hannon EC, Vigneulle R, Hellman S. Differential effects of cytotoxic agents on hematopoietic progenitors. Cancer Res 1981; 41: 2338-2342.

119. Ferrari S, Rovati B, Porta C, Alessandrino PE, Bertolini A, Collova E et al. Lack of dendritic cell mobilization into the peripheral blood of cancer patients following standard- or highdose chemotherapy plus granulocyte-colony stimulating factor. Cancer Immunol Immunother 2003; 52: 359-366.

120. Radojcic V, Bezak KB, Skarica M, Pletneva MA, Yoshimura K, Schulick RD et al. Cyclophosphamide resets dendritic cell homeostasis and enhances antitumor immunity through effects that extend beyond regulatory T-cell elimination. Cancer Immunol Immunother 2010; 59: 137-148.

121. Salem ML, El-Naggar SA, Cole DJ. Cyclophosphamide induces bone marrow to yield higher numbers of precursor dendritic cells in vitro capable of functional antigen presentation to T-cells in vivo. Cell Immunol 2010; 261: 134-143.

122. Sefc L, Psenak O, Sykora V, Sulc K, Necas E. Response of hematopoiesis to cyclophosphamide follows highly specific patterns in bone marrow and spleen. J Hematother Stem Cell Res 2003; 12: 47-61.

123. Salem ML, Kadima AN, El-Naggar SA, Rubinstein MP, Chen Y, Gillanders WE et al. Defining the ability of cyclophosphamide preconditioning to enhance the antigen-specific CD8 + T-cell response to peptide vaccination: creation of a beneficial host microenvironment involving type I IFNs and myeloid cells. J Immunother 2007; 30: 40-53.

124. Eberhard A, Kahlert S, Goede V, Hemmerlein B, Plate KH, Augustin HG. Heterogeneity of angiogenesis and blood vessel maturation in human tumors: implications for antiangiogenic tumor therapies. Cancer Res 2000; 60: 1388-1393. 
125. Miller KD, Sweeney CJ, Sledge GW Jr. Redefining the target: chemotherapeutics as antiangiogenics. J Clin Oncol 2001; 19: 1195-1206.

126. Bertolini F, Paul S, Mancuso P, Monestiroli S, Gobbi A, Shaked Y et al. Maximum tolerable dose and low-dose metronomic chemotherapy have opposite effects on the mobilization and viability of circulating endothelial progenitor cells. Cancer Res 2003; 63: 4342-4346.

127. Loeffler M, Kruger JA, Reisfeld RA. Immunostimulatory effects of low-dose cyclophosphamide are controlled by inducible nitric oxide synthase. Cancer Res 2005; 65 . 5027-5030.

128. Hodi FS, O'Day SJ, McDermott DF, Weber RW, Sosman JA, Haanen JB et al. Improved survival with ipilimumab in patients with metastatic melanoma. N Engl J Med 2010; 363 : 711-723.

129. Robert C, Thomas L, Bondarenko I, O'Day S, DJ M, Garbe C et al. Ipilimumab plus dacarbazine for previously untreated metastatic melanoma. N Engl J Med 2011; 364: 2517-2526.

130. Zielinski C, Knapp S, Mascaux C, Hirsch F. Rationale for targeting the immune system through checkpoint molecule blockade in the treatment of non-small-cell lung cancer. Ann Oncol 2013; 24: 1170-1179

131. Lorenzi S, Mattei F, Sistigu A, Bracci L, Spadaro F, Sanchez M et al. Type I IFNs contro antigen retention and survival of $\mathrm{CD} 8\{$ alpha + dendritic cells after uptake of tumor apoptotic cells leading to cross-priming. J Immunol 2011; 186: 5142-5150.

132. Vanneman M, Dranoff G. Combining immunotherapy and targeted therapies in cancer treatment. Nat Rev Cancer 2012; 12: 237-251.

133. Farsaci B, Higgins JP, Hodge JW. Consequence of dose scheduling of sunitinib on host immune response elements and vaccine combination therapy. Int J Cancer 2012; 130 1948-1959.
134. Ko JS, Zea AH, Rini BI, Ireland JL, Elson P, Cohen P et al. Sunitinib mediates reversal of myeloid-derived suppressor cell accumulation in renal cell carcinoma patients. Clin Cancer Res 2009; 15: 2148-2157.

135. Balachandran VP, Cavnar MJ, Zeng S, Bamboat ZM, Ocuin LM, Obaid H et al. Imatinib potentiates antitumor T-cell responses in gastrointestinal stromal tumor through the inhibition of Ido. Nat Med 2011; 17: 1094-1100.

136. Nefedova Y, Nagaraj S, Rosenbauer A, Muro-Cacho C, Sebti SM, Gabrilovich DI. Regulation of dendritic cell differentiation and antitumor immune response in cancer by pharmacologic-selective inhibition of the janus-activated kinase 2/signal transducers and activators of transcription 3 pathway. Cancer Res 2005; 65: 9525-9535.

137. Seeger JM, Schmidt P, Brinkmann K, Hombach AA, Coutelle O, Zigrino $P$ et al. The proteasome inhibitor bortezomib sensitizes melanoma cells toward adoptive CTL attack. Cancer Res 2010; 70: 1825-1834.

138. Boni A, Cogdill AP, Dang P, Udayakumar D, Njauw CN, Sloss CM et al. Selective BRAFV600E inhibition enhances T-cell recognition of melanoma without affecting lymphocyte function. Cancer Res 2010; 70: 5213-5219.

139. Correale P, Botta C, Cusi MG, Del Vecchio MT, De Santi MM, Gori Savellini G et al. Cetuximab +1 - chemotherapy enhances dendritic cell-mediated phagocytosis of colon cancer cells and ignites a highly efficient colon cancer antigen-specific cytotoxic T-cell response in vitro. Int J Cancer 2012; 130: 1577-1589.

140. Kim PS, Armstrong TD, Song H, Wolpoe ME, Weiss V, Manning EA et al. Antibody association with HER-2/neu-targeted vaccine enhances CD8 T-cell responses in mice through Fc-mediated activation of DCs. J Clin Invest 2008; 118: $1700-1711$. 